\title{
Corporate Governance and Financial Management Practices of Small and Medium Enterprises in the Cities Batangas Province
}

\author{
Jennifer M. Perez, CPA, PhD \\ ${ }^{*}$ Graduate School -College of Accountancy, Business, Economics and International Hospitality Management, Batangas State University \\ DOI: 10.29322/IJSRP.11.10.2021.p11867 \\ http://dx.doi.org/10.29322/IJSRP.11.10.2021.p11867
}

\begin{abstract}
The value of small and medium enterprises (SMEs) in global economic development is indispensable. Therefore, SMEs must be properly managed thru good governance. The descriptive method of research, as adopted to explore the corporate governance and financial management practices of SMEs in Batangas province. Top and middle management of 104 SMEs participated in the survey using a researcher-made questionnaire. Documentary analysis and interview with accountants, consultants and directors were also conducted to gather information. Multiple regression was used to determine the influence of corporate governance on financial management. Results showed that most of the SMEs are service business, newly operating with few employees, close corporations and has five board of directors majority of which are male. It revealed that SMEs practice corporate governance to a moderate extent while financial management is moderately practiced and that corporate governance practices has significant influence on financial management. Furthermore, some of the issues and challenges in corporate governance are awareness on the need for it, having corporate governance standard applicable to SMEs, and cost of implementing. Finally, the proposed corporate governance mechanism intends to assist SMEs in practicing good governance to enhance their financial management.
\end{abstract}

Index Terms- Corporate Governance, Corporation, Financial Management, Small and Medium Enterprises,

\section{INTRODUCTION}

Small and medium-sized enterprises (SMEs) have been recognized worldwide for their role in economic growth. These business firms collectively are contributing to every nation's trade and industry. They add in the tax revenues of the government and aid in employment generation. They are also making impact in the society as they provide arrays of products and services which drive up the competition in the market. This competition challenges business entities to become more innovative in their offerings and come up with improved and lower priced products and services.

According to World Bank, they account for about 90 percent of companies worldwide and more than half of jobs. In developing markets, formal SMEs contribute up to 40 percent of their national income. In the economies of the European Union, SMEs comprise 99.8 percent of companies contributing 67 percent of total employment in the non-financial business sector of the EU-28. At regional level, SMEs dominate Asia, accounting for more than 50 percent of employment, accounting for 95 percent of businesses in developing economies. Most firms in the Philippines belong to the micro, small and medium-sized enterprises (Dano-Luna, Canare, and Francisco, 2018).

In the Philippines Republic Act 9501 otherwise known as the Magna Carta for MSMEs defines micro, small and medium enterprises (MSMEs) as any business activity or enterprise engaged in industry, agribusiness and/or services, whether single proprietorship, cooperative, partnership or corporation whose total assets, inclusive of those arising from loans but exclusive of the land on which the particular business entity's office, plant and equipment are situated, must have value falling under the following categories: Micro enterprises are those with asset sizes of P3 million and below; Small enterprises have assets from P3,000,001 to P15 million; Mediumsized enterprises, on the other hand, have assets in the range of P15,000,001 to P100 million.

The proliferation of SMEs is notable especially with the support that the government provides. However, the sluggishness and closure of some SMEs are also noteworthy. According to Yoshino (2016), SMEs are faced with numerous challenges such as limited access to finance, lack of databases, low expenditure on research and development, undeveloped channels of sales and low levels of financial inclusion, which are some of the reasons behind slow growth and why some have run out of business. Hence, it is vital to have fully functioning support measures for them.

In order to survive and sustain operations, SMEs need to properly manage the business. This means setting goals and objectives and developing and adopting strategies that will maximize the value of the firm. This overall goal usually translates to increasing revenues and profits, minimizing its cost, boosting market share, improving and expanding customer base, promoting worker satisfaction, 
enhancing its social responsiveness and many more. To accomplish this goal, sound financial management must be in place. SMEs also need to have proper direction and control over the business to better manage it through corporate governance.

Financial management deals with the actions and decisions taken in respect of the economic resources of an organization. It includes various activities, such as the planning, controlling and decision making. It helps to decide the financial needs of the company, as well as the source of the funds needed. It is also concerned with using the funds properly to boost the competitiveness of the company. It encourages sustainability, and the utilization of resources. Financial management practices are set of activities that involve selecting assets to invest in, obtaining business funds, managing assets and ensuring effective use of those assets. They often apply to accounting for the goods and claims of the organization, as well as accurate monitoring and review of these products. Businesses gain competitive advantage through sound and efficient financial management, and enhance its sustainability and growth.

A lot of factors have influence on financial management. One of these, is the way an entity is governed because financial management involves different activities which is a result of making decisions. Governance is the system, or set of rules and policies that guide and control them. This is composed of elements which will help ensure fair and open decisions taken by the accountable individuals. It also defines the role and relationships between an organization's components.

Corporate governance practices apply to the manner in which an entity is governed and regulated, taking into account shareholder interests, equal treatment of employees, stakeholder position, disclosure and accountability and board responsibilities. The application of corporate governance ensures that corporations follow strategic goals, while the company itself adheres closely to the laws and regulations. Ultimately, every firm's governance structure serves the function of ensuring that companies are run and handled in a manner that is fair, equitable and appropriate for all stakeholders.

According to Biore, Gonzales, Caparas, Burgos, and Ballada (2015) some of the specific benefits of good governance include improved system of internal control which leads to greater accountability, protection of corporate resources and eventually, better profit margins; enhanced market value which leads to easy access to capital in financial markets, and increased credibility which enhances the flexibility of the firm. Furthermore, embracing corporate governance principles and practices affects corporate financial and non-financial value of the enterprise.

Hence, it is crucial for every organization to adopt corporate governance mechanisms because this creates a culture of transparency, awareness and clarity in management. This ensures that the company is geared toward s its long-term goals and at same time is directed towards maximizing value and goodwill. Corporate governance mechanisms is a set of authorities, responsibilities and procedures which have an influence on management decisions. These mechanisms could be internal or external which serve as a controlling tool for creating balance and safeguarding the interests of various stakeholders. Internal mechanisms are connected to board of directors, stakeholders and other internal processes and systems of the organization. While external mechanisms are the tools including auditors, market intermediaries, regulatory environment and others.

Most SMEs operate with systems, strategies and procedures less structured. Without any structured guidelines or structure, and with shareholders simultaneously serving as managers and boards of directors, SMEs face major difficulty making decisions especially those related to financial management. Connect to this the consequences of family participation in the organization at various levels. It is apparent that conventional governance systems need to be changed to meet the distinct needs of SMEs. SMEs can be guided by good governance and provided with set of tools they can use to support their survival and growth. Therefore, this requires the implementation of governance systems tailored for SMEs.

Many researches have been conducted focusing on these SMEs. Some researches focused on identifying the problems faced by SMEs while some aimed to identify the factors affecting its performance and management. Financial management is one of the many functional areas of management which is necessary to manage the financial resources of the business. Helping these SMEs in this area would help them survive and grow and is tantamount to helping alleviate the nation's economy. To enhance the management system, the structure and processes related to how decisions are made within the organization must be taken into consideration. This is why it is important to study the corporate governance and financial management practices of these SMEs.

\section{IDENTIFY, RESEARCH AND COLLECT IDEA}

This study aimed to propose corporate governance mechanisms for financial management of SMEs in Batangas Province. Specifically, it focused on the profile of SMEs and assessed their corporate governance and financial management practices. It evaluated the influence of corporate governance on financial management practices. It also determined some of the issues and challenges in corporate governance.

\section{Related Literature}


This study explores the corporate governance as well as the financial management practices of SMEs in Batangas province. This anchors on the idea that corporate governance influences financial management. Corporate governance was cited by Brigham and Houston (2013) as one of the important business trends which have profound effect on financial management.

According to Kilonzo and Ouma (2015), financial management practices include working capital management, investing, financing, financial reporting and analysis and accounting information systems. Working capital management deals with a firm's investment in short-term assets, cash, accounts receivables and inventories. Investing is concerned with the allocation of the firm's source financial resources among the available opportunities. Financing refers to the relative amount of long-term debt and equity. Financial reporting and analysis is concerned with the nature, frequency and purpose of financial reporting. It also deals with financial objectives and targets, financial budgeting and control, and analysis and interpretation of financial performances. Lastly, accounting information systems is a system that collects, records, stores and processes data to produce information for decision makers.

Corporate governance involves a set of relationships between a company's management, its board, its shareholders and other stakeholders. Corporate governance also provides the structure through which the objectives of the company are set, and the means of attaining those objectives and monitoring performance are determined (OECD, 2015). The ASEAN Corporate Governance Scorecard (2015) is basically anchored to OECD Principles of Corporate Governance. It covers five principles of corporate governance namely rights of shareholders; equitable treatment of shareholders; role of stakeholders; disclosure and transparency; and responsibilities of the board. The rights of shareholders consider how a company recognizes all shareholders' rights in conducting its business. Equitable treatment of shareholders ensures fair treatment of controlling and minority shareholders. The role of stakeholders specifies that companies should act as responsible citizens of society. Disclosure and transparency postulates that companies should disclose material corporate information in a timely and cost-effective manner. The responsibilities of the board evaluate whether the board operates within an effective corporate governance framework. These principles became the basis of researcher in assessing the corporate governance practices of SMEs.

Agency theory emphasize corporate governance is a framework in which a board of directors is a critical management mechanism to minimize the issues that the relationship with the principal agent creates (Berle and Means, 1932) In this context, agents are the managers, the owners are the principal and the board of directors act as the monitoring mechanism. The board of directors' primary duty is to shareholders to ensure that shareholder interest is maximized. Separating ownership from management may lead business managers to take action that might not optimize shareholder capital because of their firm's unique experience and skills that would favor them and not the owners; thus, a control system is intended to protect shareholder interest.

On the other hand, stakeholder theory focuses on issues affecting stakeholders within an organization. It stipulates that a corporate organization should always aim to achieve a balance between the interests of its different stakeholders to ensure that some degree of satisfaction is attained for each concern group (Abrams, 1951). This has become more prevalent as a corporate entity's actions have been recognized to have an impact on the external environment requiring the organization's accountability to a broader audience than simply its shareholders.

Agency theory emphasizes the monitoring and controlling functions of the board of directors to ensure that the managers (agent) act for the best interest of the shareholders (principal) and are connected to the rights and equitable treatment of shareholders as well as the responsibilities of the board. Stakeholder theory focuses on the role of stakeholders as part of corporate governance systems. They are associated to the corporate social responsibility of organizations and recognize that the firm owes to the society and not just to the shareholders.

\section{Research Design}

This study utilized descriptive design which according to According to Cooper and Schindler (2014) is concerned with finding out who, what, where, when, and how much. It aims to describe the phenomena or characteristics associated with a subject population. This type of research design is appropriate because it could best explain the information and attributes needed in assessing the corporate governance and financial management practices of SMEs in Batangas province. The researcher recorded all the information provided by the respondents through the self-made questionnaire, interview and documentary analysis. Frequency and percentage were used to determine the distribution of responses particularly, in SME profile, while weighted mean and standard deviation were used to present the assessments of top and middle management on corporate governance and financial management practices and issues and challenges in corporate governance. Lastly, multiple regression was applied to determine the relationship of profile variables to corporate governance practices as well as the influence of the latter on financial management practices.

\section{Participants}

The respondents in the research were top and middle management of each SME registered as corporations in Batangas province because they are basically involved and knowledgeable in the corporate governance and financial management of their respective companies. Specifically, they are the financial manager, general manager, Chief Financial Officer, Chief Executive Officer, or any equivalent position. The 104 SMEs were randomly selected from the list obtained from the Securities and Exchange Commission and Business and 
Licensing Permits of Batangas City, Lipa City and Tanauan City. The study focused of SMEs operating and registered in the said cities because of high concentration of businesses in these areas.

\section{Data Gathering Instrument}

Questionnaire was the main data gathering instrument used in the study to assess corporate governance and financial management practices of SME corporations in Batangas province. Issues and challenges on corporate governance were also gathered thru this questionnaire. The researcher-made questionnaire was composed of four parts namely, profile of the firm, assessment on the corporate governance practices and financial management practices and issues and challenges on corporate governance. The questionnaire was developed based on the ASEAN Corporate Governance Scorecards, books and materials on corporate governance and financial management. This was validated by the panel of experts. The first part which is the profile of the firm consisted of questions on the nature of its business, years of operation, number of employees, type of corporation, number of board of directors and composition of the board of directors. The second part consisted of the five areas of corporate governance practices included the rights of shareholders, equitable treatment of shareholders, role of stakeholders, disclosure and transparency and responsibilities of the board. While the financial management practices, the third part also composed of five areas namely: working capital management, investing, financing, financial reporting and analysis and accounting information system. The last part consisted of some of the issues and challenges on corporate governance.

The following scale was used to describe the corporate governance practices, financial management practices and some issues and concerns on corporate governance.

\section{Range Interpretation}

$3.50-4.00 \quad$ To a great extent/ Highly practiced/ Strongly agree

$2.50-3.49$ To a moderate extent/ Moderately practiced/ Agree

$1.50-2.49$ To a less extent/ Less practiced/ Disagree

$1.00-1.49 \quad$ To a least extent/ Least practiced/ Strongly disagree

An interview guide was also drafted to gather additional information. This is composed of fifteen open-ended questions which focus on the corporate governance practices. It also includes questions regarding the issues and challenges on corporate governance as well as suggested solutions which the informants deem applicable.

\section{Data Gathering Procedure}

The researcher distributed the survey questionnaire to the randomly selected SMEs. The respondents were given enough time to answer the questionnaire. Constant follow ups had to be made to get an update on the survey. There were some instances wherein the researcher personally assisted and guided the respondents in answering the instrument. Interview with accountants/consultants of these SMEs were also conducted. They were considered as key informants since they are familiar with the structure and operations of the business. Other means like telephone calls and text messages were also employed to ensure full coverage of the survey. Libraries and offices/agencies were visited to collect pertinent information needed in the study. Letters of request were also forwarded to respective government agencies regarding documents pertinent to the data collection and analysis.

\section{WRITE DOWN YOUR STUDIES AND FINDINGS}

Table 1

Profile of the SMEs

\begin{tabular}{llll}
\hline & & Frequency & Percentage \\
\hline Nature of Business & Service & 37 & $35.58 \%$ \\
Years in operation & 5 years and below & 32 & $30.77 \%$ \\
Number of employees & $10-99$ & 56 & $53.85 \%$ \\
Type of corporation & Close & 91 & $87.5 \%$ \\
Number of Board of Directors & 5 & 61 & $58.65 \%$ \\
& Majority (more than half) of the board & 48 & $46.15 \%$ \\
Composition of the board & are male & & \\
\hline
\end{tabular}

From the results above, it may be deducted that businesses operating in the cities of Batangas are well diversified with high concentration on service sector and other nature of businesses. The area of study is highly industrialized and commercialized with high volume of vehicles, tourists and travelers and highly populated area. Because of this, a wide variety of services may be offered to customers like leasing of properties, repair of motor vehicles, resorts and catering services, schools/training centers, contracting and trucking services and others. This is similar to the findings of 2016 Census of Philippine Business and Industry-Economy-Wide for All Establishments released by the Philippine Statistics Authority last September 27, 2019. The report indicated that among sectors, wholesale and retail trade; repair of motor vehicles and motorcycles topped the list. Accommodation and food service activities ranked second. 
The subject of the study are corporations classified as SME which explains why most of the respondents operate for 5 years and below. It can be related to the fact that they are just starting their business and start-ups usually begin as a small scale and eventually grow or run out of business as years pass by. Mendoza and Melchor (2014) pointed out that SMEs face numerous constraints to further growth and productivity. SMEs, especially start-ups, have lower probabilities of survival than larger firms, leading to high rates of market entry and exit across nearly all economic sectors.

The results also indicate that majority of the SMEs have total employee size of 10-99. This is related to the fact that most of them are in the service sector and other businesses category which are dependent on human workforce in delivering its products and services. Related to this, is the findings of Dano-Luna, Francisco and Canare (2018) which revealed that respondents belong to the small enterprise with average total employee size of 24.

Most of the SMEs are close corporations and family-owned businesses. This may be attributed to the fact that it is very common among businesses to start as sole proprietorship or partnership and as they grow and expand, they incorporate the entity. This could be the reason for having family members or close friends as incorporators. This is consistent with the findings of the study of Go (2018) wherein he found that in the Philippines, 80 percent of businesses are family owned and controlled. While in Southeast Asia, 65 percent of total listed companies in the region are family owned.

It may be noted that male dominates directorship. But in the advent of gender equality, women are now given a chance to perform an important role in the business. It is also evident that the representation of women in the board to be gradually increasing. Women empowerment is being recognized nowadays and board diversity in terms of gender diversity is believed to have a great impact in the success of a business. The study conducted by IFC revealed that across the six ASEAN countries included in their study, there is considerable variations in board gender diversity. While, Kim and Starks (2016) emphasized that the female directors contribute additional expertise to corporate boards, which results in enhanced board advisory effectiveness. The women who are appointed as corporate directors diversify the set of boards' expertise more than do their male counterparts and women bring their own unique skills to corporate boards.

Table 2

Corporate Governance Practices

\begin{tabular}{llll}
\hline \multirow{2}{*}{ Items } & \multicolumn{2}{l}{ Overall assessment } & \\
& SD & WM & Interpretation \\
\hline Rights of shareholders & 0.79 & 3.39 & Moderate Extent \\
Equitable treatment of shareholders & 0.85 & 3.34 & Moderate Extent \\
Role of stakeholders & 0.70 & 3.55 & Great Extent \\
Disclosure and transparency & 0.81 & 3.36 & Moderate Extent \\
Responsibilities of the board & 0.74 & 3.50 & Great Extent \\
\hline
\end{tabular}

Since most of the companies surveyed are close corporations, which is composed of few shareholders, it is expected for everyone to have the opportunity to ask questions to the board. It is also common among these corporations to have all its shareholders as part of the board and that they have a voice or input in managing the business as well as exercise their right to inspect the corporate books and records. It is easier and more practical for them to communicate or announce among the shareholders especially they are usually family members or relatives. Moreover, since they are very few and usually are family members, they consult each other on various issues including their basic rights as shareholders. They respect and recognize every one that is why directors are inhibited in discussion involving related party transactions or conflict of interest and conduct related party transactions fairly and objectively through proper disclosures. These very few shareholders are usually required to attend in meetings especially in cases wherein they have to cast their votes. On the contrary, it is uncommon for these corporations to practice the right to elect, remove or replace directors because shareholders because the shareholders are the ones who also occupy the directorship. It follows that nomination of candidates for board of directors is not a usual practice. Payment of dividends is also not commonly practiced as these family businesses usually appropriate their earnings for expansion.

The rights of shareholders are reflected in the Corporation Code of the Philippines. Specifically, Section 74 states that the records of all business transactions of the corporation and the minutes of any meetings shall be open to inspection by any director, trustee, stockholder or member of the corporation at reasonable hours on business days and he may demand, in writing, for a copy of excerpts from said records or minutes, at his expense. The articles of incorporation may likewise provide that all officers or employees or that specified officers or employees shall be elected or appointed by the stockholders, instead of by the board of directors. Furthermore, Section 43 of this Code states that the board of directors of a stock corporation may declare dividends out of the unrestricted retained earnings which shall be payable in cash, in property, or in stock to all stockholders on the basis of outstanding stock held by them.

SMEs consider the role of stakeholders through their corporate social responsibility (CSR) practices towards customers' welfare, creditors' rights and employees' benefit. They implement such CSR practices because they are seen to be directly connected to business operation. These are also seen as beneficial to the company because they increase profitability thru enhanced relationship with 
customers, creditors and employees. While, corporate governance related to having a whistle blowing policy is practiced to a moderate extent only operation and is considered as an additional cost with minimal benefit. Also, despite the tax incentives related to these CSR activities, those related to environment and community is practiced only to a moderate extent. Some companies find implementing them costly and entails a lot of time and effort. Puteh Salin, Nawawi and Norbit (2017) also revealed that SMEs are willing to exercise CSR as part of their operations but this practice is not as significant in comparison with other large corporations. Incentives provided by the government for the SMEs that incorporate CSR in their organizations, tax benefits and support from shareholders and others motivate them to implement CSR practices. Shortage of funds, time consuming and lack of knowledge which make it difficult for SMEs to implement.

Many companies practice reporting their financial and non-financial performance indicators as well as disclosing the direct and indirect shareholdings of major and/or substantial shareholders because these are part of the reportorial requirements of SEC, BIR and other entities. However, providing other information pertaining to biographical details, academic qualifications etc. of directors, their remuneration and their attendance details in meetings are practiced only to a moderate extent because these are not required to be disclosed. Accordingly, Almaqtari (2016) lead to conclusion that the selected sample of companies has good level of disclosure and transparency. The attributes of corporate governance examined in this study indicate that there are some mandatory and voluntary attributes. The mandatory issues are mostly legal requirements that companies have to comply with as a requirement, but the voluntary issues are not obligatory so, some companies do not comply with those issues.

The board of directors highly practiced the preparation of policies and plans to lead the organization's performance. They also manage risks as part of this to avoid business failures which resulted from inability to respond to changes and uncertain events. They also monitor the corporate governance practices to help the business improve its performance and sustainability. Imperative to this, is ensuring the integrity of the financial accounting and reporting systems thru internal controls and independent audit. On the other hand, responsibilities of the board related to remuneration, nomination and election are practiced to a moderate extent only among close SME corporations since they are composed of few shareholders who usually act also as part of the board and management. And also due to the small size of membership in the company, they do not usually set up special committees. Section 23 of the Corporation Code of the Philippines states that board of directors or trustees shall exercise the corporate powers, conduct all business, and control all the properties of the corporation. On the issue of board sub-committees, the study of Clarke and Klettner (2010), found out that several SMEs did not have separate nomination and remuneration committees because the board is so small it tends to be the whole board.

Table 2

Financial Management Practices

\begin{tabular}{llll}
\hline \multirow{2}{*}{ Items } & \multicolumn{2}{l}{ Overall assessment } & \\
& SD & WM & Interpretation \\
\hline Working capital management & 0.79 & 3.46 & Moderately Practiced \\
Investment & 1.04 & 3.00 & Moderately Practiced \\
Financing & 1.04 & 3.05 & Moderately Practiced \\
Financial reporting and analysis & 0.64 & 3.63 & Highly Practiced \\
Accounting information system & 0.62 & 3.67 & Highly Practiced \\
\hline
\end{tabular}

Most of the problems encountered by SMEs are related to cash flows which demands proper management. Preparing and reviewing cash budgets, monthly bank reconciliation and having internal controls must be performed to ensure that there is enough cash for the business. However, investing temporary idle cash in marketable securities is only moderately practiced because SMEs prefer to maintain and hold cash to be used in their daily operations. According to Bandara, Saman \& Rathnasiri (2016), the high cash balance that the SMEs have to keep is acceptable under conditions of uncertainty in the business environment. On the other hand, businesses should maintain a trade-off between liquidity and profitability. SMEs pay less attention on investment in money market instruments such as treasury bills, commercial papers etc.

Sound financial management requires proper evaluation before making investment decision. This is highly practiced among these SMEs wherein they evaluate first the benefits before making a purchase decision of fixed assets. They employ the net present value and review the efficiency of these fixed assets. However, investing in securities is not a common practice among SMEs because they do not usually have excess funds for investing. One reason related to this is the lack of knowledge of some SMEs on the different investment vehicles. Another possible reason is that they prefer liquidity rather than future earnings. So instead of investing their money in different securities they prefer to hold it for use in the operations. Most of the problems that SMEs encounter are related to cash flows or lack of finance that is why they prefer to hold cash instead of investment. Similarly, Kilonzo and Ouma (2015), revealed that though some of the SMEs may have cash for investment, the majority of them invests without evaluating the investments. They also found that only a few of the SMEs invest in real estate and at the stock exchange. This clearly shows that the convertible investments are not priority for investments for SMEs.

Lack of access to finance is one of the cited problems among SMEs. For this reason, they are choosing a source of fund based on ease 
of access or availability and in doing so, they consider their current financial leverage before obtaining a loan to maintain their liquidity. Relative to this, SMEs ensure they have enough internally generated fund that can be used in its regular operations. This could also be a reason why they do not use their excess fund, if any, in investing and also for not always declaring dividends. On the other side, issuing shares in order to raise additional fund is not usually practiced among SMEs because it is more costly. Raising fund thru stock issuance is also not easy especially because most of these SMEs are usually close corporations with limited number of shareholders. Neither do they use of hybrid sources of financing nor do they obtain funding and assistance from government organizations. Accordingly, the study of Kilonzo and Ouma (2015) also revealed that most of the SMEs use internally generated funds. The access to bank loans by SMEs is low due to factors such as lack of collateral security, high costs associated with interest rates, fear of the bureaucratic tendencies that must be followed by the banks in order to access bank loans and poor record keeping.

Business entities are required to submit reportorial documents BIR, SEC and other agencies. Relative to this, they prepare their financial statements annually which comply with accounting standards and have these financial statements audited by an independent auditor. However, not all businesses prepare financial and other analysis to assess their financial health and they do not also draft schedules, supporting schedules and other reports because this is not mandatory and is done only at the discretion of the management. Section 141 of the Corporation Code requires every corporation, domestic or foreign, lawfully doing business in the Philippines shall submit to the SEC an annual report of its operations, together with a financial statement of its assets and liabilities, certified by any independent certified public accountant in appropriate cases, covering the preceding fiscal year and such other requirements as the SEC may require. Such report shall be submitted within such period as may be prescribed by the SEC. Likewise, Rathnasiri (2014) revealed that SMEs prepare the financial statements to fulfill statutory requirements, financing requirements and day today operative requirements.

Recording business transactions, be it manual or with the aid of technology requires various source documents. These documents serve as the basis which a company recognizes and measures an economic event. These are usually required before recording because these are evidences of transactions. Throughout time this system of accounting has evolved and one of the factors that influence this is the advancement technology. Accounting information system of many companies use computer equipment and other technology in recording transactions and preparing financial reports. This speeds up the process makes regular updating of records easier. Notwithstanding the use of technology, utilizing accounting software such as Quickbooks, SAP and others among SMEs is only moderately practiced. Some of these SMEs are reluctant to use such software because of high initial high costs, lack of knowledge or some other reasons. Related to this, some SMEs do not employ an in-house accountant to take charge of the accounting department due to higher cost which is composed of the salary and benefits of the accountant compared to acquiring the accounting services of an accounting firm or freelance accountant. In the same manner, Kilonzo and Ouma (2015) revealed that most of the businesses do not have a formal accounting system, lack an operating accounting department, do not have an accountant in charge of recording all transactions and do not use computer assisted software in recording transactions. Some of the SMEs may fear to maintain formal systems because they come with maintenance costs. Furthermore, only a few of the SMEs employ accountants and put them in charge of recording transactions due to limited resources to enable SMES afford the services of professional accountants.

Table 3

Influence of Corporate Governance Practices on the Financial Management Practices (Working Capital Management)

\begin{tabular}{|c|c|c|c|c|c|}
\hline \multicolumn{2}{|c|}{ Model } & $\begin{array}{l}\text { Standardiz } \\
\text { Coefficients } \\
\text { Beta }\end{array}$ & $\mathrm{t}$ & p-values & Verbal Interpretation \\
\hline \multirow[t]{6}{*}{1} & (Constant) & & 1.540 & .125 & \multirow{3}{*}{$\begin{array}{l}\text { Significant } \\
\text { Not Significant }\end{array}$} \\
\hline & \multirow{2}{*}{$\begin{array}{l}\text { Rights } \\
\text { Equitable }\end{array}$} & .279 & 4.208 & .000 & \\
\hline & & .030 & .499 & .618 & \\
\hline & Role & .268 & 4.284 & .000 & Significant \\
\hline & Disclosure & -.125 & -1.521 & .130 & Not Significant \\
\hline & Responsibilities & .494 & 6.167 & .000 & Significant \\
\hline
\end{tabular}

a. Dependent Variable: Working Capital Management

b. P-value $=.000$, $\mathrm{f}$-value $=130.488$

c. Rsquare $=.764$

Corporate governance ensures that businesses are running in the right direction and being run well. Governance system, thru the board of directors, sets the organization's direction, formulates the strategies and makes policies. In the process of protecting the rights of shareholders, working capital management is being influenced because managers must ensure the liquidity of the business so that the firm continuously move towards creating wealth for shareholders.

This is supported by Sathyamoorthi, et. al (2018) wherein he found that corporate governance mechanisms have a significant impact on working capital management, the highest impact being reflected on inventory conversion period. The implications of these findings are that boards of directors have a significant role to play in working capital management efficiency of the companies they govern. They 
should therefore continue providing attainable policies on working capital management and remain vigilant on demanding feedback on their implementations.

Table 4 Influence of Corporate Governance Practices on the Financial Management Practices (Investment)

\begin{tabular}{|c|c|c|c|c|c|}
\hline \multicolumn{2}{|c|}{ Model } & $\begin{array}{c}\text { Standardiz } \\
\text { Coefficients } \\
\text { Beta } \\
\end{array}$ & $\mathrm{t}$ & p-values & Interpretation \\
\hline \multirow[t]{6}{*}{1} & (Constant) & & 1.982 & .049 & \\
\hline & Rights & .086 & .782 & .435 & Not significant \\
\hline & Equitable & .133 & 1.321 & .188 & Not significant \\
\hline & Role & -.089 & -.861 & .390 & Not significant \\
\hline & Disclosure & .228 & 1.670 & .096 & Not significant \\
\hline & Responsibilities & .270 & 2.032 & .043 & Significant \\
\hline
\end{tabular}

a. Dependent Variable: Investment

b. $P$-value $=.000$, $\mathrm{f}$-value $=21.789$

c. Rsquare $=0.35$

Corporate strategy is either towards growth, stability or retrenchment and relates to financial management decisions particularly in terms of investment. The results verify the influence of corporate governance practices on investment activities because this is part of the responsibilities of the board. Board of directors are responsible for setting the organization's direction, formulating strategy and policy making. Included among the tasks of the Board is ensure that the company is geared towards its overall goal. This goal usually involves growth or diversification and consequently translates to making investment decisions.

Similar to the study of Okere and Ibidunni (2019) results revealed that there exists a positive and significant relationship between corporate governance (board size, board independence and audit committee independence) and investment decisions of shareholders. Consequently, it is recommended that to further provide effective corporate governance measures, strengthening of corporate governance and accounting standards in Nigeria would go a long way in promoting investors' confidence and thereby create positive investing decision.

Table 5

Influence of Extent Corporate Governance Practices on the Financial Management Practices (Financing)

\begin{tabular}{|c|c|c|c|c|c|}
\hline \multirow{2}{*}{\multicolumn{2}{|c|}{ Model }} & \multicolumn{2}{|c|}{ Standardized } & \multirow[b]{2}{*}{ p- values } & \multirow[b]{2}{*}{ Interpretation } \\
\hline & & Coefficients & $\mathrm{T}$ & & \\
\hline \multirow[t]{6}{*}{1} & (Constant) & & 3.748 & .000 & \\
\hline & Rights & .060 & .551 & .582 & Not significant \\
\hline & Equitable & .257 & 2.577 & .011 & Significant \\
\hline & Role & -.147 & -1.431 & .154 & Not significant \\
\hline & Disclosure & .430 & 3.176 & .002 & Significant \\
\hline & Responsibilities & .016 & .125 & .901 & Not significant \\
\hline
\end{tabular}

a. Dependent Variable: Financing

b. $P$-value $=.000, \mathrm{f}$-value $=22.854$

c. Rsquare $=0.361$

Financing involves raising of funds needed and this can be sourced using debt or equity securities. Use of debt may increase the financial leverage or lower the cost of capital. Either way, both will have an impact on the shareholder value. The use of equity on the other hand, may cause dilution of control. Thus, equitable treatment of shareholders will influence the type and amount of financing to be used by the company. Disclosure and transparency involves disclosing all necessary and relevant financial and non-financial information. This practice of corporate governance will influence financing of a company because this reflects the company's credibility. The information provided by the entity becomes a basis for capital providers in providing funds of financing the business.

The findings of Al-Nodel and Hussainey (2010) suggested that managers are likely to choose higher financial leverage when they have stronger corporate governance (large number of directors on the board and higher ownership concentration). However, they did not find any statistical association between corporate governance disclosure and debt-to-equity ratio. This suggests that firm's asymmetric information is not an important driver of the financing decision of Saudi Arabian companies. This might be due to the nature of the Saudi business environment.

Table 6

Influence of Extent Corporate Governance Practices on the Financial Management Practices 
(Financial Reporting and Analysis)

\begin{tabular}{llllll}
\hline Model & $\begin{array}{c}\text { Standardized } \\
\text { Coefficients } \\
\text { Beta }\end{array}$ & $\mathrm{t}$ & $\mathrm{p}$-values & Interpretation \\
\hline $1 \quad$ (Constant) & & 7.571 & .000 & \\
& Rights & -.045 & -.581 & .562 & Not significant \\
& Equitable & .064 & .894 & .372 & Not significant \\
& Role & .495 & 6.691 & .000 & Significant \\
& Disclosure & .219 & 2.255 & .025 & Significant \\
& Responsibilities & .144 & 1.522 & .130 & Not Significant \\
\hline
\end{tabular}

a. Dependent Variable: reporting

b. P-value $=.000, \mathrm{f}$-value $=82.157$

c. Rsquare $=0.67$

Corporate governance practices influence the financial reporting and analysis of the firm, specifically, the role of stakeholders and disclosure and transparency. Stakeholders such as customers, suppliers, creditors, the society at large and many more are all considered to be users of financial reports either directly or indirectly. Hence, the way a company reports will be greatly influenced by the governance system which aims to promote disclosure and transparency and consider the welfare of stakeholders.

Similarly, Onuorah and Imene (2016) pointed out that corporate governance system of firms serves as a way of getting the directors to pursue the interest of the shareholder as it affects the financial reporting quality of such firms thereby winning the shareholders' confidence based on the quality of information in the reports. The study suggests that in the short run, corporate governance indicators and Audit quality influence the quality of financial reporting among the firms in Nigeria.

Table 7

Influence of Extent Corporate Governance Practices on the Financial Management Practices (Accounting Information System)

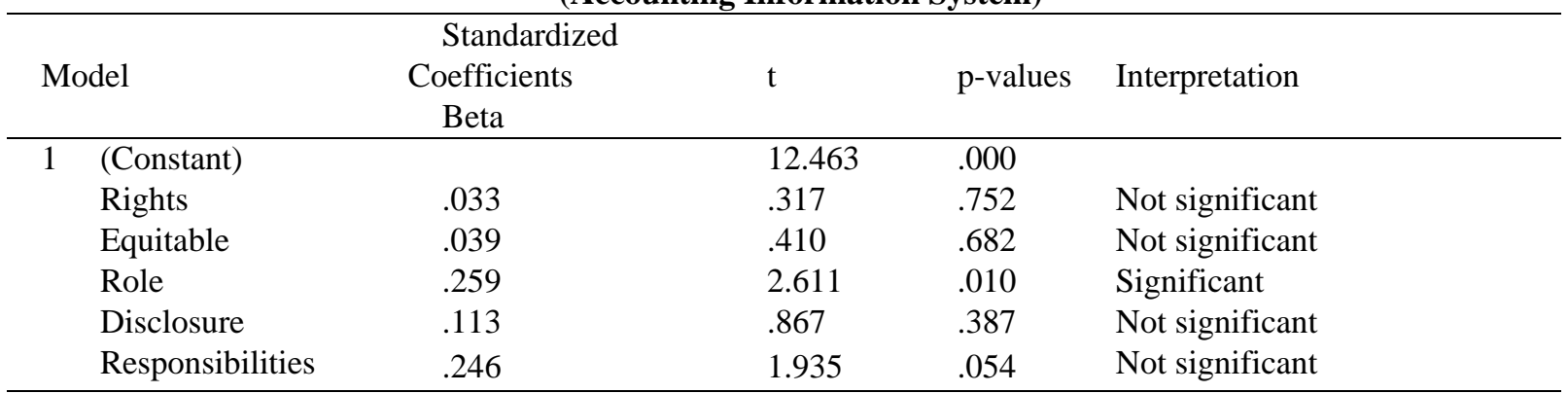

a. Dependent Variable: information

b. P-value $=.000, \mathrm{f}$-value $=27.668$

c. Rsquare $=0.406$

Corporate governance practices, particularly the role of stakeholders influence the accounting information system. Again, these stakeholders are direct or indirect users of financial information. Therefore, various stakeholders will influence the accounting information system of the firm. Information generated by businesses is typically based on the needs of its users.

According to Azim and Ara (2015), an environment is needed to practice accountability by the stakeholders of accounting which will ultimately ensure the accountability of accounting and it is possible only when there is an existence of ethical society. All the stakeholder should perform their best to uphold the accountability and they should consider it as an accountability corporate social responsibility.

Table 9

Issues and Challenges in Corporate Governance

\begin{tabular}{|c|c|c|c|}
\hline \multirow{2}{*}{ Items } & \multicolumn{3}{|c|}{ Overall assessment } \\
\hline & SD & WM & Interpretation \\
\hline $\begin{array}{l}\text { 1. Awareness on the need for corporate } \\
\text { governance. }\end{array}$ & 0.61 & 3.52 & Strongly Agree \\
\hline $\begin{array}{l}\text { 2. Corporate governance standard or guidelines } \\
\text { applicable to SMEs. }\end{array}$ & 0.66 & 3.48 & Agree \\
\hline Cost for implementing corporate governance & 0.71 & 3.42 & Agree \\
\hline
\end{tabular}

Despite the benefits of good corporate governance, practicing it is still a struggle among these SMEs. This is because some issues and challenges related to it. One of these is awareness on the need for corporate governance. SMEs may not yet recognize that benefits of 
corporate governance and may have seen only the cost associated with it. This may be connected another issue which is the lack of corporate governance standard or guidelines intended for SMEs. The existing standards are generally designed for large companies. Currently, compliance with CG standards are required only to large and publicly listed corporations. The other issue which is cost of implementing corporate governance is related to this. For practical purpose and cost savings, SMEs opted to have the same set of person/s perform these supposedly separate functions. The ACCA (2015) cited corporate governance codes typically being drafted with a view to large or listed companies. That has created a challenge for advocates of corporate governance among SMEs and private companies. These smaller companies, and even market regulators, may assume they have little corporate governance significance. Another challenge is that what is suitable for a large or listed firm may be less relevant or suitable for a family-owned SME business. In fact, the components of 'good' corporate governance for SMEs lack standardization. Additionally, some SMEs may hesitate to incorporate independent non-executive directors due to concerns about the cost of their remuneration. It is understandable that SME management and shareholders are unwilling to pay fees for non-executive directors, as funding is typically tight.

\section{Proposed Corporate Governance Mechanisms towards Sound Financial Management}

This corporate governance plan is a set of policies or guidelines, indicating how the management intends to run the company.

\section{Rights of Shareholders}

Access to information and participation in decision-making should be guaranteed to shareholders including annual shareholders 'meetings and directors' election.

- In the Annual Shareholders' Meeting Notice, state the reason and reasons for each agenda item

- Grant shareholders the right to request special meetings and issues to be discussed or placed on the ASM 's agenda.

Shareholders may provide inputs and insights in the ASM which in turn results to better working capital management as the manager ensures the liquidity of the business to continuously move towards creating wealth for shareholders.

\section{Equitable Treatment of Shareholders}

A firm must be vigilant in avoiding conflicts of interest, self-dealing, and insider trading. Its ownership structures and related transactions between parties should be fully disclosed. These initiatives provide security for investors and provide a valuable oversight position for minority investors.

- Establish a prompt, open and clear flow of knowledge with shareholders.

- Foster safe electronic voting in absentia

- Grant the right to appoint non-controlling shareholders or others who own at least more than a certain threshold

All shareholders will have a voice in the decision making particularly those related to raising of funds or financing which could result to dilution of control.

\section{Role of Stakeholders}

The organization must uphold legal rights and agreements, and co-operation between companies and stakeholders, provide access to information, and communicate breaches and remedies.

- Encourage honesty in the conduct of business and formalize the dedication, whenever possible, through an ethics pledge

- Follow socially active CSR initiatives in all their interactions with communities, ensuring that their relationship positively and consistently affects the communities

Better working capital management because as the company strives to conduct business ethically, customers become more loyal to the company, suppliers are encouraged to partner with the firm, creditors extends more funds to the company because of good reputation. This results to better liquidity position of the company. This also results to better financial reporting and analysis as well as accounting information system because as the company tries to become more socially responsible, it considers its financial implication.

\section{Disclosure and Transparency}

The board and management must set up systems for accurate reporting, as well as internal controls that mitigate risk, ensure compliance with laws and provide trust in financial and non-financial reports. A firm must have transparent accounting standards, backed up by internal and external financial statements audits. Company leaders should also promote strong ethical standards and observe it.

- Maintaining reliable account books that are audited regularly by an external auditor.

- Encourage Boards to establish policies and procedures for corporate disclosure to ensure full, accurate and timely reporting to stakeholders

- Require the Board to complement the management report by reporting to the shareholders on how it has performed its obligations.

- Include a provision in the Board Charter that directors disclose / report to the company their transactions in the company's stock within three business days

Better financial reporting and analysis and more access to finance. By having policies on maintaining a more reliable records the 
reporting and analysis of financial resources will be improved. It will become more reliable hence improving the image of the company. Because of this, obtaining funds for business becomes easier.

\section{Responsibilities of the Board}

The corporation should ensure the company's strategic guidance, the board's effective management monitoring, and the board's accountability to the firm and shareholders.

- Establish a specific policy for the board of directors to monitor the company's operating performance and to review and develop business strategies.

- Adopt a systematic procedure of choosing the successor of a chief executive and other main managers

- Provide committee charters which state their respective roles positions, responsibilities and accountabilities in simple terms

- Carry out an annual review of the CEO / Chairman, the Board as a whole, the individual directors and the board of directors

Better working capital management and investment decisions. The board of directors is primarily responsible in the direction and control of the business. Part of its responsibilities is to set the overall direction, formulate strategies and makes policies. Having a competent and effective board is crucial to working capital management and investment. Also, a clear succession plan will help a lot for the sustainability of the business.

\section{CONCLUSION}

Based on findings, most of the SMEs are service business, newly operating with few employees, close corporations and has five board of directors majority of which are male. It revealed that SMEs practice corporate governance to a moderate extent while financial management is moderately practiced and that corporate governance practices has significant influence on financial management. Furthermore, some of the issues and challenges in corporate governance are awareness on the need for it, having corporate governance standard applicable to SMEs, and cost of implementing. Finally, the proposed corporate governance mechanism intends to assist SMEs in practicing good governance to enhance their financial management.

\section{ACKNOWLEDGMENT}

The researcher would like to express her deepest gratitude first and foremost to the Lord Almighty God - the source of life, wisdom and strength. To her adviser Dr. Randy Baja for the continuous support and expert advice. To Dr. Roel Asi, Dr. Ronald Gonzales, Dr. Chrisitan Anthony Agutaya, Dr. Lolita Tegon, Dr. Aurora Tolentino, Dr. Jesus Briones, Dr. Cabrera and Dr. Rose Ecalnir for their insightful comments and encouragement which challenged the researcher to widen her perspectives. To Dr. Realiza Mame for assisting in the statistical analysis the data. To Dr. Gemar Perez, Dr. Teodorica Ani, Dr. Bendalyn Landicho, Dr. Irene Maralit, Atty. Luzviminda Rosales, Dr. Emil Alcantara, Dr. Romer Castillo, Dr. Doringer Cabrera and Dr. Roberto Gonzales for their expert advice and comments. To her Batangas State University family, PhD classmates and friends for their moral support and motivation. To all the respondents and interviewees, for generously sharing their time and participating in the study. Last but not the least, to her family for the love and support especially to her husband FO1 Marlon Perez who has been there from the very start of her PhD journey.

\section{REFERENCES}

[1] Al-Nodel, Ali and Hussainey, Khaled (2010). Corporate governance and financing decisions by Saudi companies?'. Journal of Modern Accounting and Auditing, 6 (8 SRC). pp. 1-14. ISSN 1548-6583

[2] Almaqtari, Faozi. (2016). Disclosure and Transparency of Corporate Governance Practices Evidence from India. Global Business Management Review. 1. 15-28.

[3] Bandara, S. \& Rathnasiri, U. (2016). The Working Capital Management Practices of Small and Medium Enterprises (SMEs) in Sri Lanka. Retrieved from: https://www.researchgate.net/publication/311886345

[4] Biore, C., Gonzales, R., Caparas, JL., Burgos, N. and Ballada, W. (2015). Good Governance \& Social Responsibility. DomDane Publishers.

[5] Clarke, Thomas \& Klettner, Alice. (2010). Governance Issues for SMEs. Journal of Business Systems, Governance \& Ethics. 10.15209/jbsge.v4i4.169. Retrieved from: https://www.researchgate.net/publication/266584236

[6] Cooper, D. and Schindler P. (2014). Business Research Methods 12th edition. McGraw-Hill.

[7] Dano-Luna, Maribel \& Canare, Tristan \& Francisco, Jamil Paolo. (2018). Drivers of Philippine SME Competitiveness: Results of the 2018 SME Survey. SSRN Electronic Journal. 10.2139/ssrn.3299885.

[8] Francisco, Jamil Paolo and Canare, Tristan. (2019). The Challenges to SME Market Access in the Philippines and the Role of Business Associations. Retrieved from https://apfcanada-msme.ca/research/challenges-sme-market-access-philippines-and-role-business-associations

[9] Kilonzo Jennifer M and Ouma Dennis (2015). Financial Management Practices on growth of Small and Medium Enterprises: A case of Manufacturing Enterprises in Nairobi County, Kenya. IOSR Journal of Business and Management Volume 17, Issue 8.Ver. II (Aug. 2015), PP 65-77

[10] Kim, Daehyun \& Starks, Laura. (2016). Gender Diversity on Corporate Boards: Do Women Contribute Unique Skills? †. American Economic Review. 106. 267271. 10.1257/aer.p20161032. 


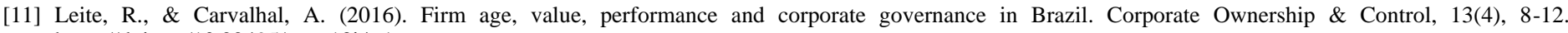
https://doi.org/10.22495/cocv13i4p1

[12] OECD (2015), G20/OECD Principles of Corporate Governance, OECD Publishing, Paris. https://doi.org/10.1787/9789264236882-en

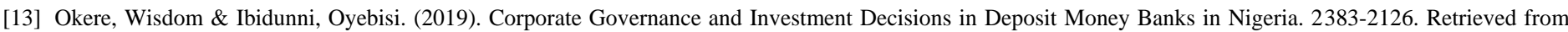
https://www.researchgate.net/publication/334284382

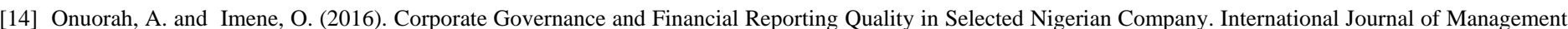
Science and Business Administration Vol. 2 Issue 3 pp 7-16.

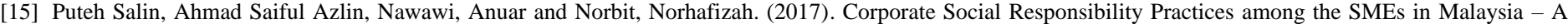
Preliminary Analysis. Retrieved from: https://www.researchgate.net/publication/325551236

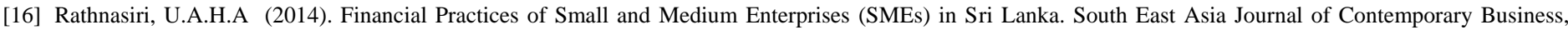
Economics and Law. Vol. 4, Issue 1

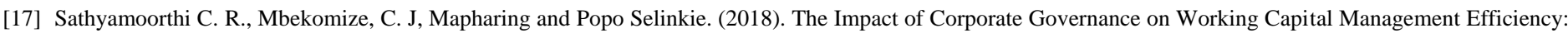

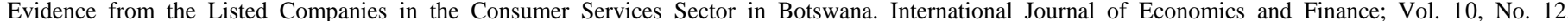
https://doi:10.5539/ijef.v10n12p135

[18] Republic Act 9501. "Magna Carta for Micro, Small and Medium Enterprises (MSMEs)".

[19] Batas Pambansa Bilang 68. "The Corporation Code of the Philippines".

[20] www.accaglobal.com

[21] www.ifc.org

[22] www.oecd.org

\section{AUTHORS}

First Author - Jennifer M. Perez, CPA, PhD, Batangas State University and jmperez1024@ gmail.com

Correspondence Author - Jennifer M. Perez, jmperez1024@ gmail.com , jennifer.perez@ g.batstate-u.edu.ph ,+639478972097 